\title{
FLOOD ENVIRONMENTAL IMPACT RISK ANALYSIS
}

\author{
MARTINA ZELEŇÁKOVÁ ${ }^{1}$, MÁRIA ŠUGAREKOVÁ ${ }^{1} \&$ PETER MÉSÁROŠ $^{2}$ \\ ${ }^{1}$ Department of Environmental Engineering, Technical University of Košice, Slovakia \\ ${ }^{2}$ Department of Construction Technology and Management, Technical University of Košice, Slovakia
}

\begin{abstract}
The aim of this paper is to determine the degree of threat in the floodplain of the Hornád river basin and to propose measures that can be used in practice at the time of the flood. The methodology is based on the principle of FEIRA (Flood Environmental Impact Risk Analysis), where the probability and consequence of the negative impact of floods on environmental components is determined on the basis of the analysis of selected stressors. From these indicators, the degree of risk in the Hornád river basin in the event of a flood is subsequently determined. Since there are several industrial sites in the solved area, which can cause extensive pollution of watercourses in case of floods, the work also presents the calculation of the threat according to the point evaluation of pollution sources. The combination of the FEIRA process and the proposed methodology for the assessment of flood environmental damage determined the overall risk of environmental damage due to floods in the Hornád catchment area. This paper is a proposal for measures to protect against floods in the area in case of floods.
\end{abstract}

Keywords: flood, environmental impact analysis, risk analysis, Hornád river basin.

\section{INTRODUCTION}

A wide range of models and case studies are used to assess flood risks. However, internationally, these models have significant economic differences. The authors Jongman et al. [1] call for the development of a consistent European framework that will apply procedures from existing models. The assessment of the economic and social impacts of floods can also be carried out using models made from topographic data of the area [2]. At the beginning of autumn 2003, a flood risk assessment study was carried out in the German Research System for Natural Disasters [3]. Flood risk is on the rise [4]-[6]. A study by Tincu et al. [7] estimates the direct damage caused by the occurrence of three floods at different times, which speaks of emphasizing the need to improve spatial plans. A study by Mishra and Sinha [8] proves that floods are one of the most devastating natural disasters, causing enormous damage to property and, in some cases, loss of life. Climate change has an impact not only on individual components of the environment, but also on the social sphere [9].

Slovakia belongs to the countries that are increasingly being affected by floods [10], [11]. In this work, the main goal is to identify and assess the impacts and impact of floods on environmental components. The impact and assessment is focused on the territory of the Hornád river basin located in the territory of the Slovak Republic. The case studies describe the methods for dealing with flood impact assessments in some countries, as well as the methods used, resp. proposed solution methodology. The following section is devoted to the description of the solved area: the partial catchment area of Hornád, to which the practical part of this work applies.

\section{STUDY AREA}

The Hornád river basin (Fig. 1) covers the territory of the Slovak and Hungarian Republics with a total area of 4,414 $\mathrm{km}^{2}$ and a length of $193 \mathrm{~km}$ in Slovakia and $93 \mathrm{~km}$ in Hungary.

The area of the Hornád sub-basin is characterized by the occurrence of impermeable and poorly permeable rocks, which have a moderate to low permeability. Rocks with good to high flow can be found in the Košice Basin and in the areas of the Slovak Karst and the 
Spiš-Gemer region. The rocks in the area of the Slovak Ore Mountains and Branisko are poorly permeable with a predominant fissure permeability. Atmospheric precipitation is the main source of groundwater in this area [12].

Part of the Hornád basin is located in the province of the Western Carpathians, a sub-province of the Inner Western Carpathians, and a smaller part of it belongs to the sub-province of the Outer Western Carpathians.

The sub-province of the Inner Western Carpathians includes the area:

- Slovak Ore Mountains,

- Fatra-Tatra region,

- Lučensko-Košice reduction,

- Matransko-Slanská area.

The areas belonging to the sub-province of the Outer Western Carpathians are the Eastern Beskydy and the Podhôlno-Magurská area.

The highest altitude of $1,401 \mathrm{~m}$ asl. occupies the smallest area of the solved area, the largest area lies at an altitude of $300-500 \mathrm{~m}$ asl. [12].

Due to the geographical location of the Hornád sub-basin, there are up to 3 climatic areas. The warm to slightly dry climatic part, characterized by a cold winter, includes the southern to south-eastern area bordering the Sabinov area. The middle part of the basin is characterized by an average total precipitation from $700-900 \mathrm{~mm}$. The climatic conditions in this district are slightly warm, slightly humid to humid. The area bordering the Volovské vrchy is characterized by a slightly cold climate. The air temperature here ranges from $4-5^{\circ} \mathrm{C}$. The annual total precipitation also exceeds $900 \mathrm{~mm}$ [12].

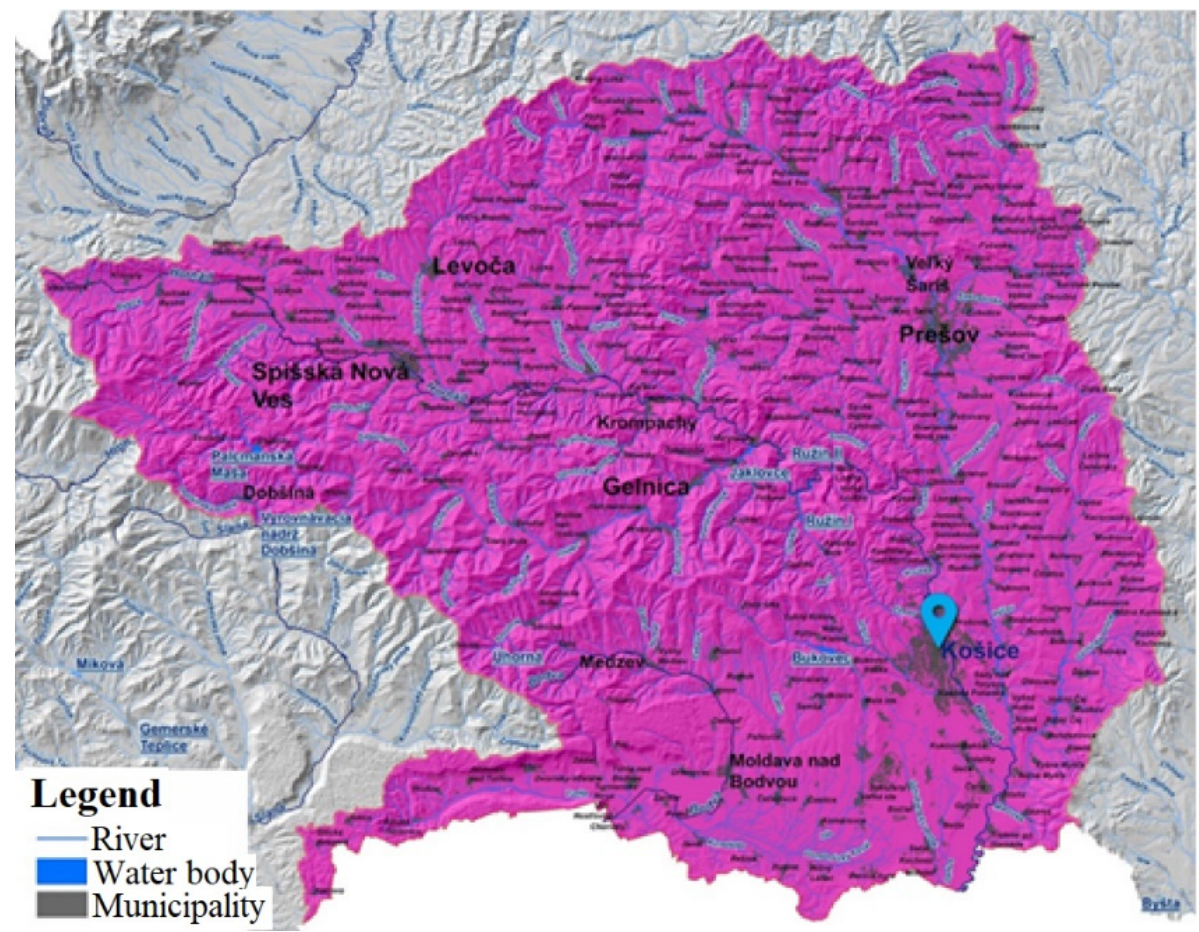

Figure 1: Study area: Hornád river basin. 
The Hornád river basin covers an area of two states. In the territory of the Slovak Republic, together with its tributaries, it occupies $81 \%$ of its total area. The most important right-hand tributary is the river Hnilec, which flows near the village of Margecany. Hnilec springs on the slope of Králová hol'a at an altitude of approximately $1740 \mathrm{~m}$ asl. It flows into the Palcmanská Maša reservoir, which is also the largest reservoir in the Slovak Paradise National Park. The flow of Hnilec continues from the dam in an easterly direction to the Ružín Reservoir.

The most significant left tributary is created by the river Torysa near the village of Nižná Myšl'a. It springs in Levočské vrchy, northwest of the village Torysky at an altitude of approximately $1215 \mathrm{~m}$ asl. Torysa flows south, flowing through the city of Prešov [12].

The Hornád river basin has a wide representation of different soil groups of geographically related soils. In the forest parts of the basin, there are mostly acidic varieties of cambium soils. These soils are very skeletal. Soils that occupy a large area in the Hornád basin are characterized by an acidic to strongly acidic soil reaction. These are soils with an insatiable sorption complex. In the Torysa basin, pseudogleies in particular are widespread. In this area, pseudogleys are arranged alternately - sorption or acid glues [12].

In the western part of the Hornád catchment area in the vicinity of Spiš, there is the Slovak Paradise mountain range, which is classified as a national park. The territory is located in the cadastral territory of the village Spišské Tomášovce. This location is rich in remarkable natural and historical monuments. The area of the Slovak Paradise National Park is $328 \mathrm{~km}^{2}$, as a protected landscape area was determined in 1964. There are 11 national nature reserves and 8 nature reserves on the territory of the Slovak Paradise [12].

The following part of the work is devoted to the methodology of assessment and analysis of individual factors affecting selected components of the environment. The final part summarizes the final values of the assessment and the overall assessment of the impact of floods on the area, as well as the assessment of flood risk.

There are several industrial sites in the Hornád sub-basin, which may pose a risk of environmental pollution in the event of floods. Summary Table 1 lists these sources of pollution. In the event of a flood at Q100, several industrial sites pose a direct threat to humans but also to the environment. Namely, there are:

- Area of VSE, Company of mechanical production Krompachy, group unclassified;

- Wastewater treatment plants (WWTP): WWTP Harichovce, WWTP Vajkovce, AGROKOV PLUS Košice, WWTP Rožkovany, WWTP Jakubova Vol'a - group of wastewater treatment plants up to 2,000 equivalent populations;

- WWTP Spišské Vlachy, WWTP Flood yard Krompachy, WWTP IMUNA PHARM Šarišské Michal'any - group of wastewater treatment plants from 2,000 to 10,000 equivalent populations;

- WWTP Spišská Nová Ves - group of wastewater treatment plants from 10,000 to 100,000 equivalent populations;

- KOVOHUTY Krompachy - group probable environmental burden,

- SEZ Krompachy - Electrical Production Plant - group of remediated or reclaimed locality.

Each pollution source is assigned an appropriate number of points according to the categorization. 


\section{MATERIAL AND METHODS}

Flood risk assessment according to the FEIRA process (Flood Environmental Impact Risk Analysis) consists of the following steps [13]-[15]. FEIRA is based on the methodology of procedures defined in ISO 31000 - Risk Management - Principles and Guidance. The FEIRA process begins with a description of the current state of the environment and the definition of sources of pollution in the area. The next step is the identification of stressors - sources of risk that pose a danger in the assessed area and represent a potential impact on environmental components. The consequence is determined by the significance of the stressor's action on the selected evaluated component. The sum of the products of these two indicators is the obtained value of the risk index [11].

The IR (risk index) is measured by the product of the probability and the consequence of individual stressors expressed by the following eqn:

$$
\mathrm{IR}=\mathrm{Pi} * \mathrm{Ci} \text {. }
$$

The probability $\mathrm{Pi}$ expresses the value of each selected stressor effect, and the consequence $\mathrm{Ci}$ expresses the value of the stressor effect on the individual components.

The value of the total risk posed by flooding in the event of floods is determined by the following eqn:

$$
\mathrm{R}=\mathrm{SUM}\left(\mathrm{Pi}{ }^{*} \mathrm{Di}\right) * \mathrm{Hi} .
$$

The hazard Hi presents the sources of pollution in the river basin [12], [13].

The goal of this contribution is effective flood risk assessment and management in the studied location which is based on current state of the environment and presence of sources of pollution in the study area. According to the proposed methodology the there are three steps:

- To calculate risk index which presents impact of stressors (floods) on components of the environment based on determined probability and determined consequence.

- To calculate risk based on hazards in the area; hazard presents point or diffuse sources of pollution in the area.

- The selection of effective measures for flood protection.

The result is the proposal of possible flood protection measures which will be effective from the viewpoint of protection (economic as well as environmental).

\section{RESULTS AND DISCUSSION}

Probability is an expression of the possibility of the occurrence of a certain phenomenon. The starting point of this methodology is the qualitative determination of probability from the lowest value $=0.25$ to the highest value 1 . Level, resp. the probability value represents a certain expectation - whether the phenomenon will happen or can happen. How the negative stressor affects selected components of the environment is expressed by the consequence. It is expressed qualitatively - as well as probability.

All assessed effects with values of causes $\mathrm{Pi}$ and their consequences $\mathrm{Ci}$ are summarized in Table 1.

According to the proposed category, the total risk level in the addressed area of the Hornád river basin is determined by a value equal to 5.5 - medium risk.

If a flood occurs in any area, it can also cause pollution of environment. There are several industrial sites in the Hornád sub-basin, which may pose a risk of environmental pollution in the event of floods. According to the categorization, each source of pollution is assigned the appropriate number of points - the Hi score (Table 2). 
Table 1: Summary of the probabilities and consequences of the impact of the flood on the environment.

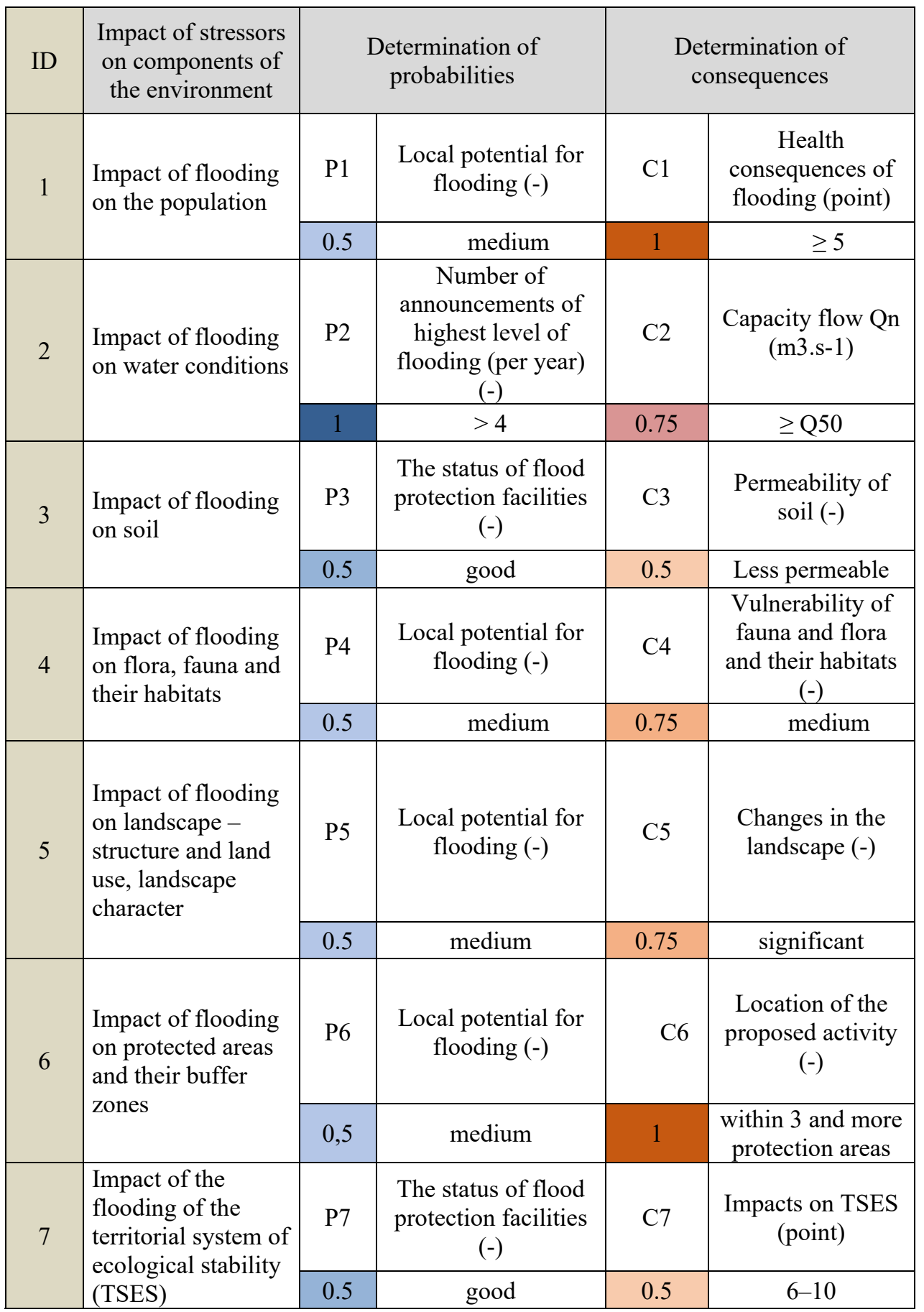


Table 1: Continued.

\begin{tabular}{|c|c|c|c|c|c|}
\hline ID & $\begin{array}{l}\text { Impact of stressors } \\
\text { on components of } \\
\text { the environment }\end{array}$ & \multicolumn{2}{|c|}{$\begin{array}{c}\text { Determination of } \\
\text { probabilities }\end{array}$} & \multicolumn{2}{|c|}{$\begin{array}{l}\text { Determination of } \\
\text { consequences }\end{array}$} \\
\hline \multirow{2}{*}{8} & \multirow{2}{*}{$\begin{array}{l}\text { Impact of flooding } \\
\text { on urban areas and } \\
\text { land use }\end{array}$} & P8 & $\begin{array}{l}\text { Local potential for } \\
\text { flooding (-) }\end{array}$ & $\mathrm{C} 8$ & $\begin{array}{l}\text { Local potential for } \\
\text { flooding (-) }\end{array}$ \\
\hline & & 0.5 & medium & 1 & $\geq 101$ \\
\hline \multirow[t]{2}{*}{9} & \multirow{2}{*}{$\begin{array}{l}\text { Impact of flooding } \\
\text { on cultural and } \\
\text { historical heritage, } \\
\text { intangible cultural } \\
\text { values }\end{array}$} & P9 & $\begin{array}{c}\text { Number of } \\
\text { announcements of } \\
\text { highest level of } \\
\text { flooding (per year) } \\
(-)\end{array}$ & C9 & $\begin{array}{c}\text { Number of } \\
\text { affected values in } \\
\text { the area (-) }\end{array}$ \\
\hline & & 1 & $>4$ & 1 & $\geq 6$ \\
\hline \multirow[t]{2}{*}{10} & \multirow{2}{*}{$\begin{array}{l}\text { Impact of flooding } \\
\text { on archaeological } \\
\text { and paleontological } \\
\text { sites and important } \\
\text { geological sites }\end{array}$} & P10 & $\begin{array}{c}\text { Number of } \\
\text { announcements of } \\
\text { highest level of } \\
\text { flooding (per year) } \\
(-)\end{array}$ & $\mathrm{C} 10$ & $\begin{array}{l}\text { Number of } \\
\text { affected sites in } \\
\text { the area (-) }\end{array}$ \\
\hline & & 1 & $>4$ & 1 & $\geq 3$ \\
\hline & & & & & 5.5 \\
\hline
\end{tabular}

The sum of the values of individual causes and consequences represents the value $\mathrm{IR}=5.5$, which is subsequently multiplied by the value of danger $\mathrm{Hi}=19$. The product of these two values is the resulting value representing the total risk $\mathrm{R}=104.5$. It presents very low risk for the Hornád river basin.

The goal of selecting effective flood protection measures in the studied territory include:

- the removing of soil deposits from the water channel and vegetation from the bank of the watercourse, thus securing the overflow capacity of the watercourse,

- for the unaltered sections of the watercourse to make modifications, e.g. to reinforce the slopes of the water channel,

- if necessary construction of a reservoir above the town which lowers the maximum overflow during increased water stages.

The construction of reservoir - dry basin above the municipality seems to be the most effective flood protection measure in the area. 
Table 2: Pollution sources with assigned number of points.

\begin{tabular}{|c|c|c|c|}
\hline $\begin{array}{l}\text { Category of source } \\
\text { of pollution }\end{array}$ & Source of pollution & Criteria & $\begin{array}{c}\text { Point } \\
\text { evaluation } H \mathrm{i}\end{array}$ \\
\hline Industrial enterprises & $\begin{array}{c}\text { Area of VSE - Enterprise of } \\
\text { mechanical production } \\
\text { Krompachy }\end{array}$ & unclassified & 5 \\
\hline \multirow{3}{*}{$\begin{array}{l}\text { Wastewater } \\
\text { treatment plants } \\
(\text { WWTP) }\end{array}$} & $\begin{array}{c}\text { WWTP Harichovce, WWTP } \\
\text { Vajkovce, AGROKOV PLUS } \\
\text { Košice, WWTP Rožkovany, } \\
\text { WWTP Jakubova Volaa }\end{array}$ & $\begin{array}{l}<2,000 \\
\text { population } \\
\text { equivalent }\end{array}$ & 1 \\
\hline & $\begin{array}{l}\text { WWTP Spišské Vlachy, } \\
\text { WWTP Povodňového dvora } \\
\text { Krompachy, WWTP IMUNA } \\
\text { PHARM Šarišské Michal'any }\end{array}$ & $\begin{array}{l}2,000-10,000 \\
\text { population } \\
\text { equivalent }\end{array}$ & 2 \\
\hline & WWTP Spišská Nová Ves & $\begin{array}{c}10,000-100,000 \\
\text { population } \\
\text { equivalent }\end{array}$ & 3 \\
\hline Agriculture & Crop production & $\begin{array}{c}10-40 \% \text { of } \\
\text { flooded area }\end{array}$ & 1 \\
\hline \multirow{2}{*}{$\begin{array}{l}\text { Environmental } \\
\text { burden }\end{array}$} & KOVOHUTY Krompachy & $\begin{array}{l}\text { Environmental } \\
\text { burden is likely }\end{array}$ & 3 \\
\hline & $\begin{array}{l}\text { SEZ Krompachy - Enterprise } \\
\text { of electric production }\end{array}$ & Land reclamation & 3 \\
\hline Urban areas & Population without sewerage & $\begin{array}{l}10-40 \% \text { from all } \\
\text { population in the } \\
\text { study area }\end{array}$ & 1 \\
\hline \multicolumn{3}{|c|}{$\operatorname{Sum} \Sigma$} & 19 \\
\hline
\end{tabular}

\section{CONCLUSION}

The first part of the practical solution of this paper was devoted to the analysis of individual stressors - floods, that have a negative impact on selected components of the environment. For each stressor impact, the probability and consequence of its effect was determined. The values were then multiplied by each other and the sum of the resulting values represents the resulting risk index. The risk index in the addressed area of the Hornád river basin is determined by a value equal to 5.5, which represents a medium level of risk level. 
In the next part, the hazard was state according to the proposed methodology [14], [15] - FRIAR. In the solved area, sources of pollution were identified, to which a point value was assigned. The resulting value represented the sum of the partial results. In the Hornád sub-basin, a low threat rate applies with a hazard value is 19 .

The final part was devoted to determining the overall risk. The resulting value of risk is the product of the resulting values of probability, consequence and threat. According to the FEIRA methodology, the first category of risk level is estimated to 104.5, which means a very low level of flood risk.

\section{ACKNOWLEDGEMENTS}

This work has been supported by the Slovak Research and Development Agency by supporting the project SK-PT-18-0008 and project SL-PL-18-0033. This work was supported by projects of the Ministry of Education of the Slovak Republic VEGA 1/0308/20 Mitigation of hydrological hazards - floods and droughts - by exploring extreme hydroclimatic phenomena in river basins.

\section{REFERENCES}

[1] Jongman B. et al., Comparative flood damage model assessment: Towards a European approach. Natural Hazards and Earth System Sciences, 12, pp. 3733-3752, 2012.

[2] Hall, J.W. et al., A methodology for national-scale flood risk assessment. Proceedings of the Institution of Civil Engineers - Water and Maritime Engineering, 156(3), pp. 235-247, 2003.

[3] Apel, H., Thieken, A.H., Merz, B. \& Blöschl, G., Flood risk assessment and associated uncertainty. Natural Hazards and Earth System Science, 4(2), pp. 295-308, 2004.

[4] Figueiredo, R., Romao, X. \& Paupério, E., Flood risk assessment of cultural heritage at large spatial scales: Framework and application to mainland Portugal. Journal of Cultural Heritage, 41, pp. 1-12, 2019.

[5] Hanák, T. \& Korytárová, J., Risk zoning in the context of insurance: Comparison of flood, snow load, windstorm and hailstorm. Journal of Applied Engineering Science. 12, pp. 137-144, 2014.

[6] Korytárová, J, Šlezingr, M. \& Uhmannová, H., Determination of potential damage to representatives of real estate property in areas afflicted by flooding. Journal of Hydrology and Hydromechanics, 55, pp. 282-228, 2007.

[7] Tincu, R., Zezere, J.L., Craciun, I., Lazar, G. \& Lazar I., Quantitative micro-scale flood risk assessment in a section of the Trotus River, Romania. Land Use Policy, 89, pp. 113, 2019.

[8] Mishra, K. \& Sinha, R., Flood risk assessment in the Kosi megafan using multi-criteria decision analysis: A hydro-geomorphic approach. Geomorphology, 350, pp. 1-19, 2020.

[9] Metz, F., Angst, M. \& Fischer, M., Policy integration: Do laws or actors integrate issues relevant to flood risk management in Switzerland? Global Environmental Change, 61, pp. 1-12, 2020.

[10] Zeleňáková, M., Preliminary flood risk assessment in the Hornád watershed. WIT Transactions on Ecology and the Environment, WIT Press: Southampton and Boston, pp. 15-24, 2009.

[11] Zeleňáková, M., Flood risk assessment and management in Slovakia. WIT Transactions on Ecology and the Environment, WIT Press: Southampton and Boston, pp. 61-69, 2011. 
[12] Ministry of the Environment of the Slovak Republic: Preliminary flood risk assessment in the Slovak Republic. Bratislava: MŽP SR, 2018. http://www.minzp.sk/files/sekciavod/hodnotenie-rizika-2018/phpr_sr2018.pdf. Accessed on: 5 Nov. 2019.

[13] Zeleňáková, M. et al., Mitigation of the Adverse Consequences of Floods for Human Life, Infrastructure, and the Environment. Natural Hazards Review, 18, pp. 1-15, 2017.

[14] Zeleňáková, M., Gaňová, L. \& Purcz, P., Flood risk assessment as part of flood defence. SGEM 2012: 12th International Multidisciplinary Scientific GeoConference, Vol. 3, Albena, Bulgaria, STEF92 Technology Ltd., pp. 679-686, 2012.

[15] Zeleňáková, M., Assessment of flood vulnerability in Bodva catchment using multicriteria analysis and geographical information systems. WIT Transactions on Ecology and the Environment, WIT Press: Southampton and Boston, pp. 51-59, 2015. 